\title{
PENGEMBANGAN MODUL BERBASIS PROBLEM BASED LEARNING PADA MATERI POLIMER KELAS XII SMK MA'ARIF NU 1 SUMPIUH
}

\author{
Mayang Larasati ${ }^{\star *}$, Anita Fibonacci ${ }^{1}$ dan Teguh Wibowo ${ }^{1}$ \\ ${ }^{1}$ Program Studi Pendidikan Kimia, Fakultas Sains dan Teknologi \\ Universitas Islam Negeri Walisongo, Jl Prof. Dr. Hamka Km. 2 Ngaliyan, \\ Kota Semarang, 50185, Indonesia \\ *Email: mayanglarasati.70@gmail.com
}

\begin{abstract}
ABSTRAK
Penelitian ini bertujuan untuk mengembangkan modul berbasis Problem Based Learning ( $P B L$ ) pada materi polimer kelas XII SMK Ma'arif NU 1 Sumpiuh. Model pengembangan $4 D$ dari Thiagarajan yaitu Define, Design, Develop dan Disseminate digunakan dalam penelitian. Subjek dalam penelitian ini adalah peserta didik kelas XII SMK Ma'arif NU 1 Sumpiuh. Hasil validasi modul oleh keseluruhan ahli memperoleh skor rata-rata sebesar $89,81 \%$ yang mana masuk pada kategori sangat layak. Hasil penilaian peserta didik terhadap modul menunjukkan persentase rata-rata sebesar $86,57 \%$ (sangat layak), sementara keseluruhan persentase skor rata-rata sebesar $89 \%$ dengan kategori sangat layak.
\end{abstract}

Kata kunci: modul, problem based learning, dan polimer.

\begin{abstract}
This research aims to develop a Problem Based Learning modules in material of the polymer class XII SMK Ma'arif NU 1 Sumpiuh. 4D model by Thiagarajan was used in this research. 4D model consist of Define, Design, Develop and Disseminate stage. Subject of research was students XII SMK Ma'arif NU 1 Sumpiuh. The expert judment result of average reached $89,81 \%$ including to a proper category. The result from students responses reached $86,57 \%$ including to a proper category, overall, the average percentage of module reached $89 \%$ including to a proper category.
\end{abstract}

Keyword: module, problem based learning and polymer.

DOI: https://doi.org/10.15575/jtk.v3i1.2038 


\section{PENDAHULUAN}

Hasil studi PISA tahun 2015 menunjukkan bahwa tingkat literasi sains peserta didik tergolong rendah, hal ini dibuktikan dengan rendahnya pencapaian peringkat literasi sains peserta didik Indonesia. Tingkat literasi sains peserta didik Indonesia berada pada peringkat 62 dari 70 negara yang mengikuti PISA (OECD, 2016). Sementara itu, 41\% peserta didik Indonesia memiliki pengetahuan sains yang terbatas dan hanya sedikit yang mampu menerapkannya pada situasi nyata, namun tidak ada satupun peserta didik Indonesia yang secara konsisten mampu mengidentifikasi, menjelaskan, dan menerapkan pengetahuan sains pada situasi yang berbeda (Permanasari, 2014).

Rendahnya tingkat literasi sains peserta didik Indonesia ini diduga karena sistem pembelajaran yang kurang relevan, termasuk dalam pemilihan bahan ajar (Fibonacci \& Sudarmin, 2014; Rusilowati, Nugroho, \& Susilowati, 2016; Rusilowati, Kurniawati \& Nugroho, 2016). Pemilihan bahan ajar memegang peranan penting dalam pencapaian standar kompetensi dan kompetensi dasar yang harus dicapai peserta didik (Masruroh, 2015). Beberapa prinsip harus diperhatikan di dalam pengembangan modul salah satunya yaitu prinsip relevansi (Akbar, 2013).

Mahaffy (2012) menyatakan bahwa masih minimnya sumber belajar yang menunjukkan bahwa kimia merupakan aktivitas modern yang menyenangkan dan relevan untuk memecahkan masalah yang penting. Oleh karena minimnya bahan ajar berupa modul yang menghubungkan konten materi dengan permasalahan nyata peserta didik, maka perlu dikembangkan modul PBL (Problem Based Learning).

$P B L$ melatih peserta didik untuk mengkombinasi pengetahuan yang telah dimiliki untuk mengembangkan pengetahuan yang lebih tinggi yang dapat digunakan untuk memecahkan masalah (Gagne, 1970). Pembelajaran berbasis masalah menekankan prinsip pemikiran kritis dan strategi

pemecahan masalah. Pembelajaran berbasis masalah bertujuan untuk mempercepat proses dan efisiensi penalaran klinis dengan menempatkan pembelajaran di sebuah konteks fungsional (Heliker, 1994). Karena PBL membutuhkan situasi bermasalah yang menantang secara intelektual para siswa, membutuhkan keterlibatan siswa dalam mengangkat dan mendiskusikan isu-isu yang berkaitan dengan pengelolaan masalah. Hal ini membantu siswa untuk berpikir kritis dan memecahkan masalah (Hamdan et al., 2014).

Treagust et al. (2000) menyatakan bahwa alasan utama tantangan dalam belajar dan memahami kimia adalah kimia dianggap sebagai ilmu yang tidak berhubungan dengan kehidupan sehari-hari dan hanya sains akademis. Wu (2003) menjelaskan situasi ini mengisolasi pengetahuan sekolah dari pengalaman hidup sehari-hari siswa menyebabkan terbentuknya dua hal yang tidak berhubungan dengan sistem pengetahuan dalam pikiran mereka. Pertama adalah mereka menggunakan pemecahan masalah yang ditemui dalam kelas sains mereka, dan yang kedua digunakan untuk memecahkan masalah di kehidupan nyata mereka.

Salah satu konsep kimia yang menjadi kendala bagi peserta didik adalah polimer. Hasil wawancara guru kimia di SMK Ma'arif NU 1 Sumpiuh menyatakan bahwa materi polimer merupakan salah satu materi ajar yang dianggap sulit bagi peserta didik, dikarenakan penggunaan polimer banyak kita jumpai dalam peralatan rumah tangga maupun pruduk industri. Selain itu didapatkan informasi bahwa peserta didik kurang mampu mengaplikasikan materi polimer yang didapatkan di kelas untuk mengatasi permasalahan yang dihadapi di kehidupan nyata peserta didik. Peserta didik masih kesulitan terutama membedakan dan mengelompokkan jenis-jenis plastik yang digunakan sehari-hari. Contohnya pada penggunaan kode plastik, plastik yang seharusnya digunakan sekali pakai, digunakan ulang oleh peserta didik, atau penggunaan plastik untuk kemasan makanan panas tanpa tahu dampaknya bagi kesehatan peserta didik. Oleh karena itu materi polimer 
menjadi sangat penting untuk dipelajari dan dipahami secara mendalam, bukan hanya sekedar untuk dihafalkan tetapi dengan menghubungkannya dengan permasalahan sehari-hari. Dengan demikian, modul hasil pengembangan yang menghubungkan konten materi dengan permasalahan nyata diharapkan mampu mengatasi permasalahan yang dihadapi peserta didik.

Pentingnya pembelajaran melalui permasalahan-permasalahan dunia nyata akan membimbing peserta didik untuk memecahkan permasalahan yang kompleks (Silver, 2004), termasuk di dalamnya adalah masalah lingkungan yang dapat dijadikan sebagai sumber belajar (Sukmawardani \& Hardiyanti, 2017). Penggunaan permasalahan dunia nyata bertujuan untuk menyusun pengetahuan peserta didik dan mengembangkan keterampilan berpikir peserta didik dalam pemecahan masalah (Arends, 2007). Peserta didik menyusun pengetahuan mereka sendiri yang secara tidak langsung melatih mereka untuk berpikir analitis (Rahmawati \& Buranda, 2013). Berdasarkan uraian di atas, pembelajaran $P B L$ yang dijadikan sebagai basis dalam pengembangan modul polimer diharapkan dapat mendukung tercapainya tujuan pembelajaran.

\section{METODE PENELITIAN}

Penelitian ini dilakukan di SMK Ma'arif NU 1 Sumpiuh. Penelitian dilakukan pada bulan Juni 2017. Subjek penelitian adalah peserta didik kelas XII TKJ. Model pengembangan yang digunakan dalam penelitian ini adalah model 4D (Define, Design, Develop, dan Disseminate) (Thiagarajan, 1974). Tahap disseminate tidak dilaksanakan karena keterbatasan waktu dan biaya. Adapun prosedur penelitian mencakup define, design, dan develop.

Tahap define meliputi lima langkah analisis. Analisis yang dilakukan yaitu analisis ujung depan, peserta didik, tugas, konsep, dan tujuan pembelajaran. Sumber data pada analisis diperoleh dari peserta didik dan guru kimia di SMK Ma'arif NU 1 Sumpiuh.
Selanjutnya tahap design, pada tahap ini merancang prototipe modul berdasarkan hasil analisis dari tahap define. Hal ini bertujuan agar modul yang dikembangkan sesuai dengan kebutuhan peserta didik. Tahap yang terakhir yaitu develop, pada tahap ini dilakukan uji kelayakan atau validasi ahli yang terdiri dari ahli materi dan ahli media, serta dilakukan uji pengguna yang dilakukan oleh peserta didik untuk mengetahui respon peserta didik terhadap modul $P B L$ yang dikembangkan.

Teknik pengumpulan data yang dilakukan yaitu observasi, wawancara, kuesioner, dan dokumentasi. Metode wawancara dilakukan pada peserta didik guru kimia di SMK Ma'arif NU 1 Sumpiuh, observasi untuk mengamati aktivitas peserta didik, kuesioner untuk mengetahui respon peserta didik dan dokumentasi untuk mengambil data nilai peserta didik.

Data yang diperoleh dari tiga tahap yang telah dilakukan dianalisis dengan teknik analisis data yang sesuai dengan tujuan penelitian dan pengembangan yaitu validitas modul. Menentukan validitas modul (\%) dapat menggunakan rumus sebagai berikut:

Validasi $=\frac{\text { Skor total } \text { yang diperoleh }}{\text { skor maksimal }} \times 100 \%$ (Akbar, 2013).

\section{HASIL DAN PEMBAHASAN}

Hasil penelitian ini adalah karakteristik dan kelayakan modul berbasis problem based learning. Pengembangan modul ini berusaha mengenalkan isu sosial. Peningkatan relevansi dilakukan dengan cara menyajikan isu sosial terkait lingkungan berupa sampah di Pantai Ayah dalam segmen "penyajian masalah" yang merupakan bagian langkah pertama dalam $P B L$. Hal ini dilakukan apersepsi untuk menarik peserta didik sependapat dengan Arora (2004) yang menyatakan bahwa bahan ajar $P B L$ mengharuskan peserta didik untuk memperoleh semua informasi yang relevan dengan masalah yang ada. 
Fenomena lingkungan dapat digunakan sebagai alat pembelajaran yang dapat menjadi jembatan yang menghubungkan antara teori dengan kehidupan nyata peserta didik, yaitu sampah plastik yang ada di Pantai Ayah. Topik lingkungan Pantai Ayah menarik untuk dijadikan sebagai sumber belajar yang dapat mengaitkan permasalahan sampah pantai dengan materi polimer yang ada di sekolah. Penggunaan masalah dalam modul yang dikembangkan oleh peneliti diharapkan dapat merangsang keterampilan pemecahan masalah peserta didik.

Penggunaan lingkungan sekitar sebagai alat pembelajaran akan menjadikan pembelajaran lebih bermakna (meaningful learning) karena peserta didik mengetahui materi pelajaran yang dipelajari bermanfaat bagi kehidupan sehari-hari (Afcariano, 2008). Hal ini sepadan dengan pendapat Abdullah \& Ridwan (2008) yang menyatakan bahwa meaningful learning erat kaitannya dengan pembelajaran berbasis masalah $(P B L)$, dalam pembelajaran ini peserta didik tidak diberikan pengetahuan dalam bentuk jadi melainkan peserta didik menemukan sendiri. Sehingga pada pembelajaran $P B L$ peserta didik akan menghubungkan informasi baru dengan struktur kognitif yang telah dimiliki peserta didik.

\subsection{Kelayakan Modul Berbasis Problem Based Learning}

Uji validitas modul menggunakan angket lembar validasi BSNP. Penilaian terhadap validitas produk dilakukan oleh dosen ahli di bidang konten polimer dan dosen ahli desain dan layout modul. Aspek kelayakan materi terdiri dari aspek isi, penyajian dan bahasa. Hasil kelayakan modul dari segi materi ditunjukkan pada Tabel 1.

Hasil skor rata-rata aspek yang diperoleh ahli materi 1 didapat skor sebanyak 94\% yang merupakan gabungan dari masing-masing aspek isi $96,43 \%$, aspek penyajian $93,75 \%$ dan aspek bahasa 92,5\%, berdasarkan Tabel 1 dikategorikan sangat layak sehingga tidak perlu direvisi. Ahli materi 1 hanya memberikan sedikit masukan yaitu tampilan gambar pada petunjuk penggunaan modul lebih baik diperbesar sehingga lebih jelas.

Tabel 1. Hasil Kelayakan Modul Ahli Materi

\begin{tabular}{|c|c|c|c|c|}
\hline \multirow[b]{2}{*}{ Aspek } & \multicolumn{2}{|c|}{ Validator } & \multirow[b]{2}{*}{$\begin{array}{c}\text { Rata- } \\
\text { rata }\end{array}$} & \multirow[b]{2}{*}{ Kategori } \\
\hline & $\begin{array}{c}\text { Ahli } \\
\text { materi } \\
1(\%)\end{array}$ & $\begin{array}{c}\text { Ahli } \\
\text { materi } \\
2(\%)\end{array}$ & & \\
\hline Isi & 96,43 & 100 & 98,2 & $\begin{array}{l}\text { Sangat } \\
\text { layak }\end{array}$ \\
\hline Penyajian & 93,75 & 100 & 96,875 & $\begin{array}{l}\text { Sangat } \\
\text { layak }\end{array}$ \\
\hline Bahasa & 92,5 & 92,5 & 92,5 & $\begin{array}{l}\text { Sangat } \\
\text { layak }\end{array}$ \\
\hline
\end{tabular}

Hasil validasi oleh ahli materi 2 diperoleh persentase total sebanyak $97 \%$ yang merupakan jumlah dari aspek isi $100 \%$, aspek penyajian $100 \%$ dan aspek bahasa $92,5 \%$. Mengacu pada Tabel 1 penilaian ahli materi 2 terhadap modul berbasis $P B L$ dikategorikan sangat layak tanpa revisi. Hasil uji kelayakan dari ahli materi mendapatkan skor rata-rata sebesar 95,8\% dapat disimpulkan bahwa modul yang dikembangkan masuk dalam kategori sumber belajar sangat layak.

Tabel 1 menunjukkan bahwa modul yang dikembangkan memperoleh kriteria sangat layak dari ahli materi 1 dan ahli materi 2 yang telah memenuhi komponen materi, komponen penyajian dan komponen bahasa. Komponen materi yang pertama yaitu keakuratan fakta, hal ini terlihat dari penggunaan isu lingkungan yang bersentuhan langsung dengan subjek penelitian. Peneliti mengenalkan isu tentang sampah plastik di Pantai Ayah sebelum menjelaskan konten materi polimer. Hal ini dilakukan agar tidak terjadi gap antara teori dengan konsepsi peserta didik. Contoh penyajian isu lingkungan dengan materi yang akan diajarkan dapat dilihat pada Gambar 1. Modul yang relevan dengan kehidupan peserta didik dapat digunakan sebagai pengantar pelajaran kimia dan sangat cocok untuk peserta didik yang sudah terbiasa bekerja secara mandiri (Blonder et al., 2008). Fakta yang disajikan dalam modul sesuai dengan kenyataan dan meningkatkan pemahaman konsep peserta didik. Fakta yang disajikan dalam modul diambil dari permasalahan yang ada di lingkungan peserta didik. Sepadan dengan hal tersebut, Silver 
(2004) menyatakan bahwa pembelajaran berbasis masalah sangat cocok membantu pelajar menjadi peserta didik aktif karena menempatkan pembelajaran dalam masalah dunia nyata dan membuat peserta didik bertanggung jawab atas pembelajaran mereka.

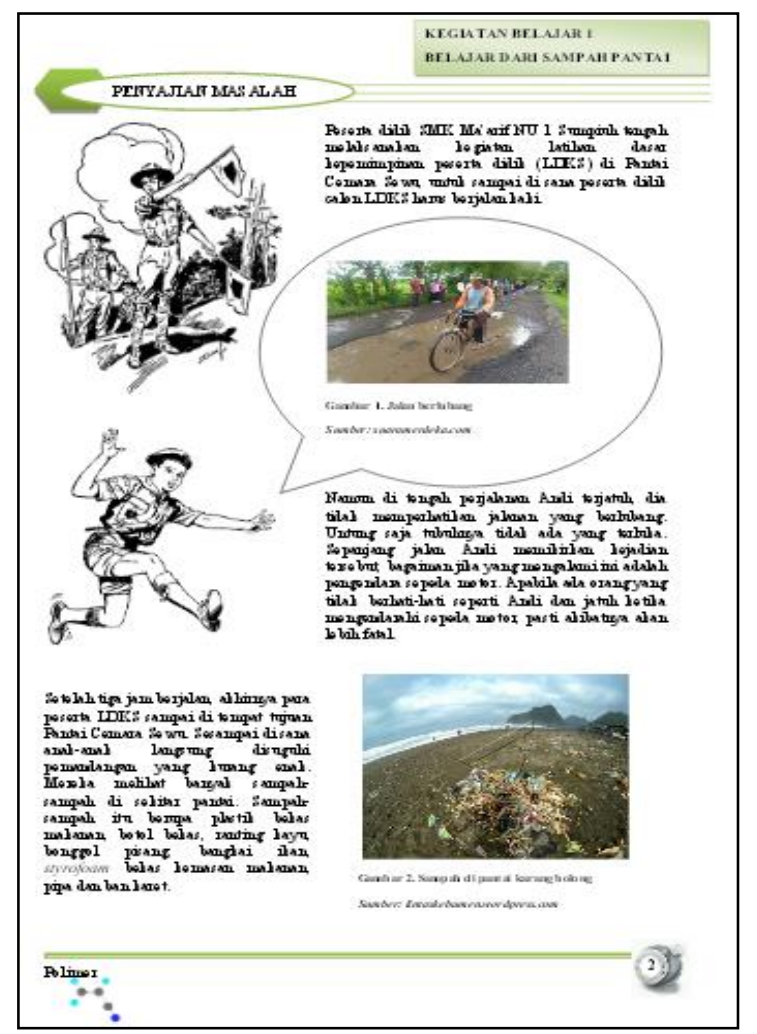

\section{Gambar 1. Penggunaan Isu Lingkungan pada Awal Materi}

Komponen yang kedua yaitu keterkinian fitur (contoh-contoh) dengan kehidupan nyata. Uraian dan contoh-contoh yang disajikan dalam modul relevan dan menarik serta mencerminkan kondisi terkini peserta didik. Prinsip-prinsip yang diterapkan dalam modul menyajikan konten yang erat kaitannya dengan permasalahan sehari-hari peserta didik. Penyajian konten yang erat kaitannya dengan kehidupan nyata mampu meningkatkan rasa ingin tahu dan tantangan belajar lebih jauh pada peserta didik. Contoh uraian dalam modul yang mencerminkan kejadian atau kondisi terkini peserta didik dapat dilihat pada Gambar 2.

Sebagai contoh, fakta yang disajikan berjudul "Polimer Pencegah Banjir atau Erosi".
Penambahan segmen fakta menarik didasari oleh banyaknya informasi yang belum diketahui peserta didik, yang sebenarnya informasi tersebut sangat bermanfaat untuk lingkungan mereka.

Hal ini sepadan dengan penelitian Kristianti (2015) yang menyatakan bahwa penyajian materi yang erat kaitannya dengan permasalahan sehari-hari mampu menumbuhkan rasa ingin tahu dan minat peserta didik untuk membaca.

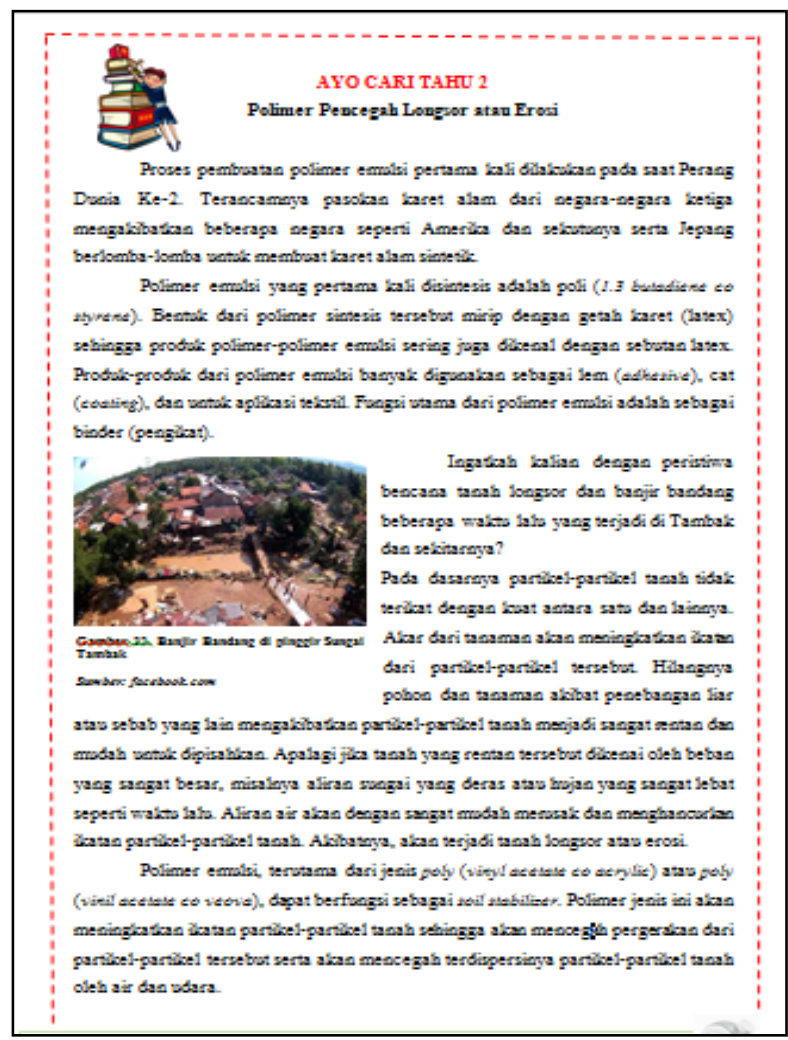

\section{Gambar 2. Uraian dalam Modul yang Mencerminkan Kondisi Terkini Peserta Didik}

Komponen penyajian yaitu penyajian materi dilakukan secara konsisten, runtut dan bersistem membuat materi mudah dipahami dan menumbuhkan motivasi peserta didik (Kurniasari dkk., 2014). Komponen penyajian yang pertama yaitu konsistensi sistematika sajian dan keruntutan penyajian. Semua konsep yang disajikan dalam modul diurutkan dari yang mudah ke rumit, dari nyata ke abstrak, dari yang sederhana ke yang kompleks, dan dari yang dikenal sampai yang belum dikenal. Materi yang disusun dalam 
modul yang dikembangkan sesuai dengan silabus kurikulum 2013, yang dimulai dari menjelaskan pengertian polimer, pembentukan polimer, struktur polimer, pengelompokan polimer, kegunaan polimer dalam kehidupan sehari-hari dan menjelaskan dampak negatif penggunaan polimer serta merancang solusi untuk menanggulangi dampak negatif polimer dalam kehidupan sehari-hari. Hal ini sesuai dengan pernyataan Martin (2012) yang menyatakan bahwa pola penyajian materi secara sistematis mampu membantu peserta didik dalam memahami isi materi ajar.

Komponen penyajian yang kedua yaitu kesesuaian ilustrasi dengan materi dan penyajian materi yang komunikatif, seolaholah peserta didik berkomunikasi dengan penulis buku. Hal ini sesuai dengan pendapat Kurniasari dkk. (2014) yang menyatakan bahwa penyajian materi mudah dipahami oleh peserta didik dengan menggunakan ilustrasi dan menggunakan kalimat yang sederhana dan lugas sehingga mudah dipahami oleh peserta didik.

Komponen penilaian bahasa terdiri atas kesesuaian tingkat perkembangan berpikir peserta didik, pemahaman peserta didik terhadap pesan, ketepatan tata bahasa dan ketepatan ejaan. Komponen bahasa yang pertama yaitu bahasa yang digunakan sesuai dengan tingkat perkembangan peserta didik, bahasa yang digunakan mampu menjelaskan konsep maupun ilustrasi dan menggambarkan contoh konkret sampai contoh abstrak sesuai dengan tingkat pemahaman dan tingkat usia peserta didik. Rosyidah dkk. (2013) menyatakan bahwa penggunaan bahasa yang sesuai dengan tingkat perkembangan peserta didik mampu meningkatkan pemahaman peserta didik terhadap materi ajar.

Komponen bahasa yang kedua yaitu pemahaman peserta didik terhadap materi ajar yang disajikan dengan bahasa yang mudah dipahami dan tidak menimbulkan multitafsir. Hal ini sejalan dengan Asfiah dkk. (2013) yang menyatakan bahwa peserta didik akan lebih mudah memahami informasi apabila bahasa yang digunakan dalam modul menarik dan terhindar dari makna ganda.

Komponen bahasa yang ketiga yaitu ketepatan tata bahasa. Tata bahasa yang digunakan dalam menyampaikan materi ajar, sesuai dengan kaidah tata bahasa Indonesia yang baik dan benar. Komponen bahasa yang keempat yaitu ketepatan ejaan, semua ejaan yang digunakan untuk menyampaikan materi ajar mengacu pada pedoman Ejaan Yang Disempurnakan (EYD). Hal ini sependapat dengan Sujiono (2014) bahwa penggunaan bahasa Indonesia dalam modul yang dikembangkan harus disesuaikan dengan kaidah tata bahasa Indonesia dan mengacu pada Ejaan Yang Disempurnakan (EYD). Konsistensi penggunaan istilah harus diperhatikan untuk menghindari kesalahpahaman bagi peserta didik ketika memahami bacaan dalam modul.

Hasil uji kelayakan dari aspek desain dan layout mendapatkan skor sebesar 88,89\%, dapat disimpulkan bahwa modul yang dikembangkan masuk dalam kategori sumber belajar sangat layak.

Berdasarkan Tabel 2, hasil validasi oleh ahli media menunjukkan skor sebanyak $88,89 \%$ dengan kategori sangat layak untuk digunakan tanpa revisi. Hasil ini telah memenuhi indikator keberhasilan yang telah ditetapkan. Beberapa komponen yang mendapat skor maksimal diyakini berperan besar dalam pencapaian peningkatan skor. Komponen yang mendapat skor 4 yaitu komponen tipografi cover dan isi modul, ilustrasi cover, dan tata letak buku. Desain sampul modul dapat dilihat pada Gambar 3.

Tabel 2. Hasil Validasi Ahli Media

\begin{tabular}{|c|l|c|}
\hline No. & \multicolumn{1}{|c|}{ BUTIR } & SKOR \\
\hline 1 & Ukuran & 3 \\
\hline 2 & Tata letak kulit buku & 4 \\
\hline 3 & Tipografi cover buku & 4 \\
\hline 4 & llustrasi cover buku & 4 \\
\hline 5 & Tata letak konsisten & 3 \\
\hline 6 & Unsur tata letak harmonis & 3 \\
\hline 7 & $\begin{array}{l}\text { Penempatan dan penampilan } \\
\text { unsur tata letak }\end{array}$ & 3 \\
\hline 8 & Tipografi isi buku & 4 \\
\hline
\end{tabular}




\begin{tabular}{|c|c|c|}
\hline No. & BUTIR & SKOR \\
\hline 9 & $\begin{array}{l}\text { Ilustrasi isi menimbulkan daya } \\
\text { Tarik }\end{array}$ & 4 \\
\hline \multicolumn{2}{|c|}{ Jumlah } & 32 \\
\hline \multicolumn{2}{|c|}{ Persentase } & $88,89 \%$ \\
\hline
\end{tabular}

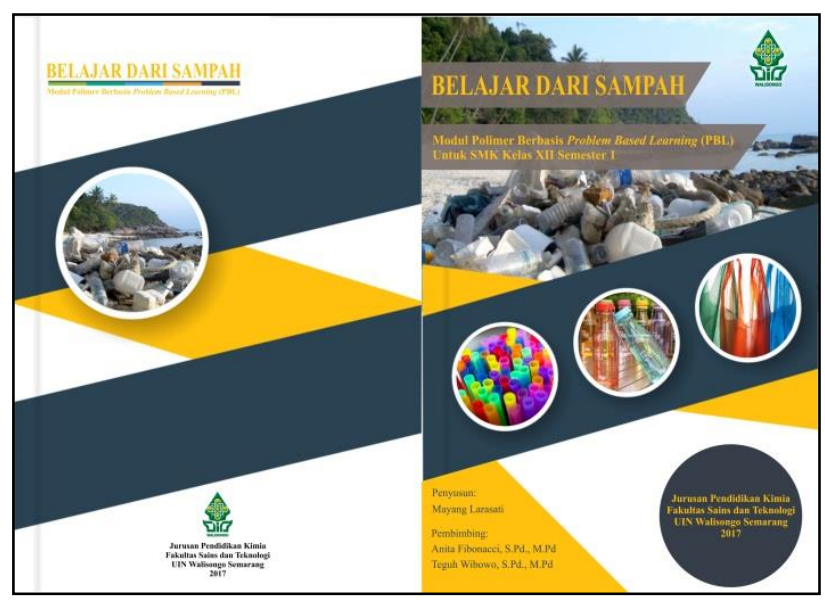

Gambar 3. Tampilan sampul modul

Aspek desain dan layout pada modul yang dikembangkan terdapat beberapa komponen. Komponen yang pertama yaitu ilustrasi cover modul. Ilustrasi pada cover modul menggambarkan isi atau materi ajar. Ilustrasi pada cover modul berupa fenomena sampah plastik di Pantai Ayah menggambarkan isi atau materi ajar yang merupakan materi polimer. Bentuk, warna dan ukuran secara proporsional sesuai dengan realita objek. Sutrisno (2008) menyatakan bahwa pemberian daya tarik seperti desain sampul yang menarik serta ilustrasi yang sesuai merupakan salah satu elemen penting dalam modul. Faktanya modul ini memberikan gambar dan ilustrasi berupa anak pramuka yang sedang melakukan kegiatan di pantai dan menemukan banyak sampah plastik yang berserakan. Pemberian gambar dan ilustrasi bertujuan untuk menarik minat baca peserta didik serta mempermudah peserta didik mengetahui isi dari buku yang dicerminkan pada sampul (Kurniasari dkk., 2014).

Komponen yang kedua yaitu tata letak kulit buku. Penataan tata letak pada cover depan dan belakang memiliki kesatuan yang harmonis sehingga memberikan kesan irama yang baik. Komposisi tata letak dan kekontrasan (judul, pengarang, ilustrasi, dan logo) seimbang dengan tata letak isi sehingga menampilkan pusat pandang (center point) baik dan jelas. Hal ini sepadan dengan pendapat Saputra dkk. (2013) yang menyatakan bahwa pusat pandang (center point) yang baik dapat meningkatkan daya tarik peserta didik untuk membaca modul.

Komponen yang ketiga yaitu modul $P B L$ yang dikembangkan tidak menggunakan kombinasi jenis huruf yang terlalu banyak. Jenis huruf yang digunakan pada cover modul disamakan dengan jenis huruf pada isi modul yaitu menggunakan jenis huruf Times New Roman. Saputra dkk. (2013) menyatakan bahwa penggunaan jenis huruf yang terlalu banyak dapat mengganggu perserta didik dalam menyerap informasi yang disampaikan.

Komponen yang keempat yaitu tipografi isi modul. Penggunaan variasi huruf tidak berlebihan, hal tersebut bertujuan untuk mempermudah peserta didik dalam memahami materi yang terdapat pada modul (Kurniasari dkk., 2014). Besar huruf disesuaikan dengan tingkat pendidikan peserta didik yaitu 10pt untuk ukuran teks dan 14 pt untuk ukuran judul.

\subsection{Uji Kelayakan Modul}

Uji kelayakan modul dilakukan pada kelompok kecil yaitu sembilan peserta didik dengan kategori tiga orang kelompok berkemampuan tinggi, tiga orang kelompok berkemampuan sedang dan tiga orang kelompok berkemampuan rendah. Hasil skor tanggapan peserta didik menunjukkan bahwa skor pada kelompok berkemampuan tinggi menghasilkan skor tertinggi dengan rata-rata skor $89,95 \%$, untuk hasil skor angket tanggapan peserta didik terlihat perbedaan yang tidak terlalu tinggi pada kelompok berkemampuan sedang dan rendah yaitu $84,26 \%$ dan $85,18 \%$. Oleh karena itu diperoleh skor rata-rata keseluruhan yang diberikan peserta didik terhadap modul yang dikembangkan adalah $86.57 \%$, berdasarkan Tabel 3 maka termasuk dalam kategori sangat layak dan boleh digunakan tanpa direvisi. 


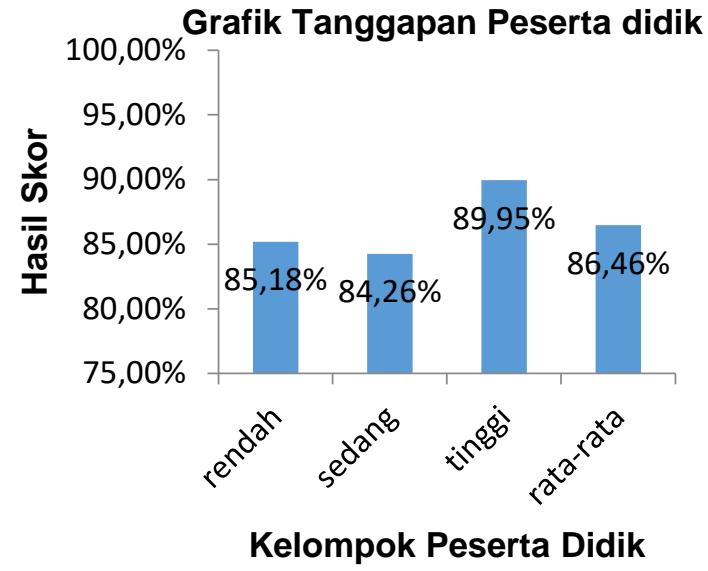

Gambar 4. Hasil Skor Respon Peserta Didik

Hasil angket tanggapan yang diberikan kepada peserta didik memperoleh persentase skor paling tinggi pada komponen tampilan cover yaitu $97,22 \%$, hal ini menunjukkan peserta didik sepakat bahwa cover modul sudah menarik dan menggambarkan secara keseluruhan isi modul.

Angket tanggapan yang diberikan peserta didik pada komponen bahasa memperoleh skor yang tinggi yaitu 94,44\%. Hasil tanggapan peserta didik menyatakan bahwa bahasa yang digunakan dalam modul mudah dipahami. Hal ini menunjukkan bahwa modul yang dikembangkan sudah menggunakan bahasa yang telah disesuaikan dengan tingkat perkembangan dan penguasaan bahasa peserta didik.

\section{KESIMPULAN}

Hasil penelitian dapat disimpulkan bahwa modul berbasis Problem Based Learning $(P B L)$ pada materi polimer layak untuk digunakan. Rata-rata nilai kelayakan modul oleh pakar mencapai $89,81 \%$, dengan kategori sangat layak. Persentase respon peserta didik diperoleh nilai sebesar $86,57 \%$ dengan kategori sangat layak. Sehingga diperoleh persentase nilai rata-rata sebesar $89 \%$ dengan kategori sangat layak. Berdasarkan hasil uji validitas modul, maka modul ini dinyatakan layak sebagai bahan ajar peserta didik. 


\section{DAFTAR PUSTAKA}

Abdullah, A. G. \& Ridwan, Taufik. (2008). Implementasi Problem Based Learning pada Proses Pembelajaran di BPTP Bandung. Bandung: Universitas Pendidikan Pendidikan.

Afcariano, Muchamad. (2008). Penerapan Pembelajaran Berbasis Masalah untuk Menaingkatkan Kemampuan Berpikir Kritis Siswa pada Mata Pelajaran Biologi. Jurnal Pendidikan Inovatif, 3(2), 65-68.

Akbar, Sa'dun. (2013). Instrumen Perangkat Pembelajaran. Bandung: PT Remaja Rosdakarya.

Arends, Richard I. (2007). Belajar untuk Mengajar. Edisi ketujuh. Terjemahan Helly dan Sri. Yogyakarta: Pustaka Pelajar.

Arora, A. (2004). Problem-Based Learning. CIDR Teaching and Learning Bulletin Problem-Based Learning. 7 (3). (http://www.washitongton.edu/teaching/) , diakses 9 Oktober 2017.

Asfiah, N., Mosik, \& Purwantoyo, E. (2013). Pengembangan Modul IPA Terpadu Kontekstual pada Tema Bunyi. Unnes Science Education Journal, 2(1), 188195.

Blonder, R., Kipnis, M., Mamlok-Naaman, R., \& Hofstein, A. (2008). Increasing Science Teachers' Ownership through the Adaptation of the PARSEL Modules: A" Bottom-up" Approach. Science Education International, 19(3), 285-301.

BSNP. (2014). Instrumen Penilaian Buku Teks Pelajaran. Jakarta: BSNP.

Fibonacci, Anita, \& Sudarmin. (2014). Development Fun-Chem Learning Materials Integrated Socio-Science Issues to Increase Students Scientific Literacy, IJSR, 3(11), 708-713.
Gagne, R. M. (1970). The Condition of Learning (2nd ed.). New York, N. Y.: Holt, Rinehart and Winston.

Hamdan, A. R., Kwan, C. L., Khan, A., Ghafar, M. N. A., \& Sihes, A. J. (2014). Implementation of Problem Based Learning among Nursing Students. International Education Studies, 7(7), 136-142.

Heliker, D. (1994). Meeting The Challenge of The Curriculum Revolution: Problem Based Learning in Nursing Education. Journal of Nursing Education, 33(1), 4547.

Kristianti, Eka. (2015). Pengembangan Bahan Ajar Berbasis Masalah dan Keterampilan Berpikir Tingkat Tinggi Berpendekatan Saintifik dalam Pembelajaran Fisika. Tesis. Semarang: Fakultas Matematika dan IImu Pengetahuan Alam Universitas Negeri Semarang.

Kurniasari, D. A. Rusilowati, A., \& Subekti, N. (2014). Pengembangan Buku Sumplemen IPA Terpadu dengan Tema Pendengaran Kelas VII. Unnes Science Education Journal, 3(2), 462-467.

Mahaffy. (2012). Where Chemical Education is Heading: Interview with Peter Mahaffy. Chemistryviews. USA 6 November 2016.

Martin, Putut. (2012). Pengembangan Bahan Ajar Science Enterpreneurship Berbasis Hasil Penelitian untuk Mendukung Program Kreatifitas Mahasiswa. Jurnal Penelitian Pendidikan, 2 (29), 101-108.

Masruroh, A. (2015). Pengembangan Modul Pembelajaran Menulis Cerpen Berbasis Pengalaman (Experiential Learning) untuk Siswa SMP/MTs. Skripsi. Yogyakarta: Fakultas Bahasa dan Seni Universitas Negeri Yogyakarta.

OECD. (2016). PISA 2015 Results in Focus. (https://www.oecd.org/pisa/pisa-2015- 
results-in-focus.pdf), diakses 11 Desember 2017.

Permanasari, Anna. (2014). Kurikulum 2013: Implikasinya dalam Pembelajaran di Sekolah, Pendidikan Profesi dan Pendidikan Tinggi. Prosiding Seminar Nasional. Palopo 3 Mei 2014.

Rahmawati, Amirudin, A., \& Buranda, J. P. (2013). Pengaruh Model Pembelajaran Problem Based Learning Terhadap Kemampuan Berpikir Analitis pada Mata Pelajaran Geografi Siswa SMA. 1-12. (http://jurnal-online.um.ac.id/), diakses 29 Agustus 2017.

Rosyidah, A. N., Sudarmin, \& Siadi, K. (2013). Pengembangan Modul IPA Berbasis Etnosains Zat Adiktif dalam Bahan Makanan untuk Kelas VIII SMP Negeri Pegandon Kendal. Unnes Science Education Journal, 2(1), 133-139.

Rusilowati, A., Kurniawati, L. \& Nugroho, S. E. (2016). Developing an Instrument of Scientific Literacy Asessment on the Cycle Theme. International Journal Of Environmental \& Science Education, 11(12), 5718-5727.

Rusilowati, A., Nugroho, S. E., \& Susilowati, S. M. E. (2016). Development of Science Textbook Based on Scientific Literacy For Secondary School. Jurnal Pendidikan Fisika Indonesia, 12(2), 98105.

Saputra, A., Nurjannah, \& Lamba, H. A. (2013). Pengembangan Bahan Ajar Fisika Materi Suhu dan Kalor Berbasis Budaya Masyarakat Trans Lalundu. Jurnal Pendidikan Fisika Tadulako, 1(4), 54-60.

Silver, Cindy E.H. (2004). Problem-Based Learning: What and How Do Students Learn?. Educational Psychology Review, 16(3), 235-236.

Sujiono. (2014). Pengembangan Modul IPA Terpadu Berbasis Problem Based
Learning Tema Gerak untuk Meningkatkan Kemampuan Berpikir Kritis Siswa. Skripsi. Fakultas MIPA Universitas Negeri Semarang.

Sukmawardani, Y., \& Hardiyanti, R. (2017). Pengembangan Lembar Kerja Berbasis Inkuiri Untuk Analisis Kualitatif Logam Berat pada Limbah Laboratorium. Jurnal Tadris Kimiya, 2(2), 153-158

Sutrisno, Joko. (2008). Teknik Penyusunan Modul. Direktorat Sekolah Menengah Kejuruan, Dirjen Manajemen Pendidikan Dasar dan Menengah. Depdiknas: Jakarta.

Thiagarajan, Semmel. (1974). Instructional Development for Training Teachers of Exceptional Children. Bloomington: Indiana University.

Treagust, D., Duit R., \& Nieswandt M. (2000). Sources of Students' Difficulties in Learning Chemistry. Educacio' $N$ Qui'Mica, 11(2), 228-235.

Wu HK. (2003). Linking The Microscopic View of Chemistry to Real Life Experiences: Intertextuality in A High School Science Classroom. Sci Educ, 87(6), 868-891. 